\title{
Combined Neurofilament Light and Optical Coherence Tomography Better Predicts Multiple Sclerosis Disease Activity Than Either Measure Alone
}

Julia Krämer, MD, Heinz Wiendl, MD, Sven G. Meuth, MD, PhD, and Philipp Albrecht, MD

Neurol Neuroimmunol Neuroinflamm 2021;8:e1054. doi:10.1212/NXI.0000000000001054

Multiple sclerosis (MS) shows significant interindividual and intraindividual heterogeneity regarding radiologic and histopathologic features, clinical appearance, disease course, and therapy response. ${ }^{1}$

Reliable biomarkers that could (1) predict the individual disease course, (2) identify those patients with MS who would profit of initial high-efficacy disease-modifying therapies, and (3) predict individual treatment response are therefore urgently needed. ${ }^{2}$ Besides several other candidates, serum neurofilament light chain (sNfL) protein and optical coherence tomography (OCT) measurements have been proposed as potential surrogate markers to aid in the assessment of disease activity, treatment response, or prognostication in MS..$^{3-9}$

In this issue, Lin et al. ${ }^{10}$ investigated the potentially additive value of a combination of sNfL protein together with OCT measurements as a "compound biomarker" for subsequent disease activity in patients with clinically isolated syndrome (CIS) and early relapsing-remitting MS (RRMS). Seventy-eight patients (16 with CIS and 62 with RRMS) were examined with OCT, and their sNfL protein values were determined early in the course of disease. Patients were clinically examined for up to 2 years and categorized into patients with abnormal or normal sNfL protein level $(\geq /<80$ th age-specific percentile), thin or thick ganglion cell and inner plexiform (GCIP) layer thickness (median divider, $\leq />70.4 \mu \mathrm{m}$ ), thin or thick peripapillary retinal nerve fiber layer (pRNFL) thickness (median divider, $\leq />100 \mu \mathrm{m}$ ), and thick or thin inner nuclear layer (INL) thickness (median divider, $\geq /<36.4 \mu \mathrm{m}$ ) at baseline. No evidence of disease activity (NEDA-3) criteria violation and its components in the next 2 years was the primary outcomes. Five major observations were made as follows: (1) increased sNfL protein level at baseline was correlated with GCIP layer but not pRNFL or INL thickness; (2) increased sNfL protein level but not pRNFL, GCIP layer, or INL thickness was associated with future NEDA-3 violation and development of new lesions; (3) thinner GCIP layer was associated with future relapses but not new lesions; (4) neither abnormal sNfL protein level, abnormal OCT parameters nor their combination was correlated with future disability accrual; and (5) combinations of increased sNfL protein levels with thinner GCIP layer, thinner pRNFL, or thicker INL were associated with higher risk of NEDA-3 violation than each parameter alone.

Although patients with abnormal sNfL protein level and thin GCIP layer at baseline had approximately $40 \%$ and $30 \%$ higher risk of not meeting NEDA-3 after 1-year follow-up, respectively, the combination of abnormal sNfL protein level and thin GCIP layer was associated with an approximately $60 \%$ increased risk compared with normal sNfL protein level and thick GCIP layer.

\author{
Correspondence \\ Dr. Krämer \\ julia.kraemer@ukmuenster.de \\ or Prof. Albrecht \\ phil.albrecht@gmail.com
}

\section{RELATED ARTICLE}

Increased Serum Neurofilament Light and Thin Ganglion Cell-Inner Plexiform Layer Are Additive Risk Factors for Disease Activity in Early Multiple Sclerosis

Page e1051

From the Department of Neurology with Institute of Translational Neurology (J.K., H.W.), University Hospital Münster, Germany; and Department of Neurology (S.G.M., P.A.), University Hospital Düsseldorf, Germany. 
Previous studies demonstrated a correlation between thin pRNFL, GCIP layer, and low total macular volume with increased risk of future disability worsening ${ }^{4,5,7}$ and thin $\mathrm{PRNFL}$ and GCIP layer with future NEDA-3 violation. ${ }^{6}$

The value of this study ${ }^{10}$ is that it provides a "proof of concept" that the combination of biomarkers is more precise than each marker alone. Because OCT parameters are structural markers of previous neuroaxonal damage and sNfL protein is a body fluid biomarker reflecting ongoing, most likely acute or subacute, neuronal damage and thus disease activity, the combination of both measures provides complementary information. Although the authors used the median values of their cohort as dividers for each OCT parameter, it will be important to verify whether these cutoffs are also applicable to other cohorts. The sample size of 78 patients was small, the dropout rate of 50\%-70\% was high, and the follow-up with 720 days was rather short, warranting confirmation in independent studies. Baseline serum sampling and OCT examinations were performed between 12 and 24 months after disease onset. Shifting the time point to the time of diagnosis when patients are treatment naive may further increase the predictive value.

It would be interesting to investigate how the predictive value of OCT and SNfL protein for NEDA-3 compares with other established biomarkers such as MRI measures (lesion load or global or regional brain volumes) and CSF markers such as oligoclonal bands and if future brain atrophy or cognitive decline can be predicted. Furthermore, it would be important to evaluate whether these measurements can be combined to an even more sophisticated composite multimodal biomarker and they can also be used in patients with progressive MS.

OCT measurements were analyzed using the Heidelberg Engineering device, and levels of sNfL protein were quantified using the single molecule array by QUANTERIX. Future research is required to validate these assessments across different platforms.

In summary, the combination of sNfL protein and OCT parameters seems to be a very promising composite biomarker that can easily be obtained to predict future disease activity. It is important to note that the findings have to be confirmed in larger prospective and multicenter studies involving earlier time points and longer follow-up and to evaluate whether the predictive potential of sNfL protein and OCT measurements demonstrated on a group level can be confirmed for the individual patient level. In case of a positive result, the combination of abnormal sNfL protein level and OCT parameters could already serve as the "tip on the scale" in uncertain treatment decisions.

\section{Study Funding}

No targeted funding reported.

\section{Disclosure}

J. Krämer received honoraria for lecturing from Biogen, Novartis, Merck Serono, Roche, Mylan, and Teva and financial research support from Sanofi Genzyme. H. Wiendl received compensation for serving on Scientific Advisory Boards/Steering Committees from Bayer Healthcare, Biogen Idec, Sanofi Genzyme, Merck Serono, and Novartis. He has received speaker honoraria and travel support from Bayer Vital GmbH, Bayer Schering AG, Biogen, CSL Behring, EMD Serono, Fresenius Medical Care, Genzyme, Merck Serono, Omniamed, Novartis, and Sanofi Aventis. He has received compensation as a consultant from Biogen Idec, Merck Serono, Novartis, Roche, and Sanofi Genzyme. Heinz Wiendl also received research support from Bayer Healthcare, Bayer Vital, Biogen Idec, Merck Serono, Novartis, Sanofi Genzyme, Sanofi US, and Teva. S. G. Meuth received honoraria for lecturing and travel expenses for attending meetings from Almirall, Amicus Therapeutics Germany, Bayer Health Care, Biogen, Celgene, Diamed, Genzyme, MedDay Pharmaceuticals, Merck Serono, Novartis, Novo Nordisk, ONO Pharma, Roche, Sanofi-Aventis, Chugai Pharma, QuintilesIMS, and Teva. His research is funded by the German Ministry for Education and Research (BMBF), Deutsche Forschungsgemeinschaft (DFG), Else Kröner Fresenius Foundation, German Academic Exchange Service, Hertie Foundation, Interdisciplinary Center for Clinical Studies (IZKF) Muenster, German Foundation Neurology, Almirall, Amicus Therapeutics Germany, Biogen, Diamed, Fresenius Medical Care, Genzyme, Merck Serono, Novartis, ONO Pharma, Roche, and Teva. P. Albrecht received grants and nonfinancial support from Biogen; grants, personal fees, and nonfinancial support from Allergan; personal fees and nonfinancial support from Bayer; personal fees and nonfinancial support from Merck; grants, personal fees, and nonfinancial support from Merz Pharmaceuticals; grants, personal fees, and nonfinancial support from Novartis; grants, personal fees, and nonfinancial support from Roche; grants, personal fees, and nonfinancial support from Teva; and grants, personal fees, and nonfinancial support from Ipsen, outside the submitted work. Go to Neurology.org/NN for full disclosures.

\section{References}

1. Reich DS, Lucchinetti CF, Calabresi PA. Multiple sclerosis. New Engl J Med. 2018; 378(2):169-180.

2. Comabella M, Montalban X. Body fluid biomarkers in multiple sclerosis. Lancet Neurol. 2014;13(1):113-126.

3. Kuhle J, Kropshofer H, Haering DA, et al. Blood neurofilament light chain as a biomarker of MS disease activity and treatment response. Neurology. 2019;92(10): e1007-e1015.

4. Rothman A, Murphy OC, Fitzgerald KC, et al. Retinal measurements predict 10-year disability in multiple sclerosis. Ann Clin Transl Neurol. 2019;6(2):222-232.

5. Lambe J, Fitzgerald KC, Murphy OC, et al. Association of spectral-domain OCT with long-term disability worsening in multiple sclerosis. Neurology. 2021;96(16) e2058-e2069.

6. Zimmermann HG, Knier B, Oberwahrenbrock T, et al. Association of retinal ganglion cell layer thickness with future disease activity in patients with clinically isolated syndrome. JAMA Neurol. 2018;75(9):1071-1079.

7. Martinez-Lapiscina EH, Arnow S, Wilson JA, et al. Retinal thickness measured with optical coherence tomography and risk of disability worsening in multiple sclerosis: a cohort study. Lancet Neurol. 2016;15(6):574-584.

8. Thebault S, Abdoli M, Fereshtehnejad SM, Tessier D, Tabard-Cossa V, Freedman MS. Serum neurofilament light chain predicts long term clinical outcomes in multiple sclerosis. Scientific Rep. 2020;10(1):10381

9. Knier B, Schmidt P, Aly L, et al. Retinal inner nuclear layer volume reflects response to immunotherapy in multiple sclerosis. Brain. 2016;139(11):2855-2863.

10. Lin T-Y, Vitkova V, Asseyer S, et al. Increased serum neurofilament light and thin ganglion cell-inner plexiform layer are additive risk factors for disease activity in early multiple sclerosis. Neurol Neuroimmunol Neuroinflamm. 2021;8(5):e1051. 


\title{
Neurology \\ Neuroimmunology \& Neuroinflammation
}

\author{
Combined Neurofilament Light and Optical Coherence Tomography Better Predicts \\ Multiple Sclerosis Disease Activity Than Either Measure Alone \\ Julia Krämer, Heinz Wiendl, Sven G. Meuth, et al. \\ Neurol Neuroimmunol Neuroinflamm 2021;8; \\ DOI 10.1212/NXI.0000000000001054
}

This information is current as of August 4, 2021

\section{Updated Information \& \\ Services}

References

Subspecialty Collections

Permissions \& Licensing

Reprints including high resolution figures, can be found at:

http://nn.neurology.org/content/8/5/e1054.full.html

This article cites 10 articles, 1 of which you can access for free at: http://nn.neurology.org/content/8/5/e1054.full.html\#\#ref-list-1

This article, along with others on similar topics, appears in the following collection(s):

Multiple sclerosis

http://nn.neurology.org//cgi/collection/multiple_sclerosis

Information about reproducing this article in parts (figures,tables) or in its entirety can be found online at:

http://nn.neurology.org/misc/about.xhtml\#permissions

Information about ordering reprints can be found online: http://nn.neurology.org/misc/addir.xhtml\#reprintsus

Neurol Neuroimmunol Neuroinflamm is an official journal of the American Academy of Neurology.

Published since April 2014, it is an open-access, online-only, continuous publication journal. Copyright

Copyright $\odot 2021$ The Author(s). Published by Wolters Kluwer Health, Inc. on behalf of the American

Academy of Neurology.. All rights reserved. Online ISSN: 2332-7812.

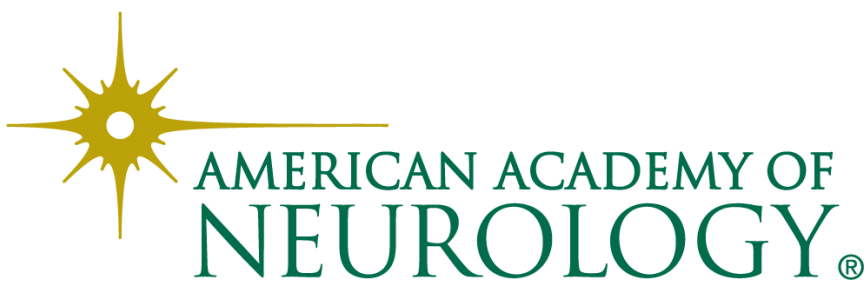

